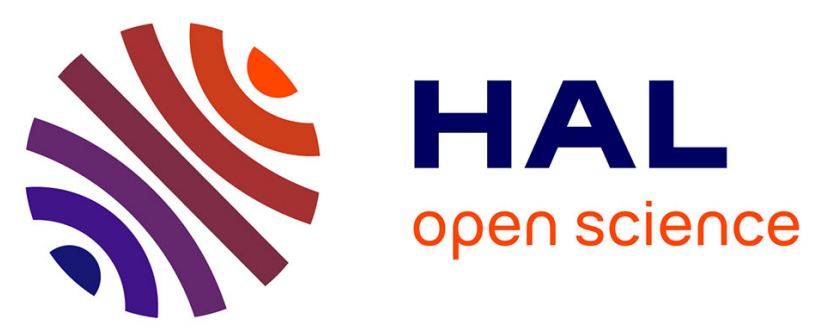

\title{
Chain conformation of polybutadiene blocks in lamellar bidispersed microdomains as revealed by small-angle neutron scattering
}

\author{
G. Evmenenko, V. Alexeev, A. Vilesov
}

\section{To cite this version:}

G. Evmenenko, V. Alexeev, A. Vilesov. Chain conformation of polybutadiene blocks in lamellar bidispersed microdomains as revealed by small-angle neutron scattering. Journal de Physique IV Proceedings, 1993, 03 (C8), pp.C8-53-C8-58. 10.1051/jp4:1993811 . jpa-00252241

\section{HAL Id: jpa-00252241 \\ https://hal.science/jpa-00252241}

Submitted on 1 Jan 1993

HAL is a multi-disciplinary open access archive for the deposit and dissemination of scientific research documents, whether they are published or not. The documents may come from teaching and research institutions in France or abroad, or from public or private research centers.
L'archive ouverte pluridisciplinaire HAL, est destinée au dépôt et à la diffusion de documents scientifiques de niveau recherche, publiés ou non, émanant des établissements d'enseignement et de recherche français ou étrangers, des laboratoires publics ou privés. 


\title{
Chain conformation of polybutadiene blocks in lamellar bidispersed microdomains as revealed by small-angle neutron scattering
}

\section{G.A. EVMENENKO, V.L. ALEXEEV and A.D. VILESOV*}

Petersburg Nuclear Physics Institute, Academy of Sciences of Russia, Gatchina, St. Petersburg dist. 188350, Russia

"Institute of Macromolecular Compounds, Academy of Sciences of Russia, St. Petersburg 199004, Bolshoi 31, Russia

\begin{abstract}
Polybutadiene-polygtyrene diblock copolymer lamellar supercrystals developed by binary mixture of PS-PB block copolymerg with different molecular weights have been studied by SaNS on the diffractometer "Kembrana-2". The dependence of the lattice spacing and the radil of grration of PB chains on the molecular-welght parameters of a domain have been studied. It tumed out that the conformation of $\mathrm{PB}$ chatns is dependent on the concentration of surrounding short chains.
\end{abstract}

\section{Introduction.}

The present paper 1s devoted to the study of block copolymer chain conformations in binary mixtures of polystyrene-polybutadiene (PS-PB) diblock copolymers with different molecular welghtg by small-angle neutron scattering techniques. It 1s common knowledge that the perfect domain structures in a wide range of polydispersity and composition are developed by such kinds of mixtures [1]. Recently a mean-field theory has been proposed for structures of this kind [2]. In this theory bidlsperged diblock copolymer chains grafted to a plane surface are examined. According to this theory the domain consists of two sublayerg (P1g.1). In the lower sublaver the conformation of those parts of the long chains which are in the sublayer 
occupled by short chains is similar to that of the short chains.

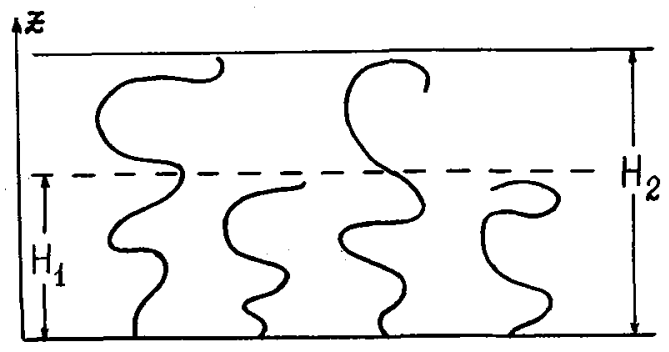

P1g.1. Structure of bidispersed domain.
Only those parts of the long chatns which are in the the range $\mathrm{H}_{1} \leqslant \mathrm{z} \leqslant \mathrm{H}_{2}$ (where $\mathrm{H}_{2}$ 1s the full layer helght, $H_{1}$ is the height of ghort chains, $z$ is the coordinate along the normal to the grafting surface) are perturbed due to spreading in the lateral directions.

\section{Experimental.}

The gamples of the PS-PB diblock copolymers have been gynthesized in the Institute of Macromolecular Compounds, Academy of Sciences of Husg1a. Their molecular parameterg are given in Table 1.

Table 1

Molecular parameters of block copolymers

\begin{tabular}{|c|c|c|c|c|c|c|}
\hline & Polymer & $\begin{array}{c}\text { Praction } \\
\text { PS }\end{array}$ & $H_{B O} \cdot 10^{-3}$ & $\underset{\mathrm{BO}}{\overline{\mathrm{m}}_{\mathrm{w}} / \bar{M}_{\mathrm{n}}}$ & ${ }_{\mathrm{P}} \cdot 10^{-3}$ & ${ }_{\mathrm{p}}^{\mathbf{p}_{\mathrm{PB}} \cdot 10^{-3}}$ \\
\hline 1 & PS-PB & 0.65 & 108 & 1.04 & 68 & 38 \\
\hline 2 & PS-PB & 0.61 & 312 & 1.06 & 184 & 119 \\
\hline 3 & $P S-P B^{d}$ & 0.45 & 279 & 1.04 & 120 & 146 \\
\hline
\end{tabular}

We intended to study the conformation of polybutadiene chaing of the $\mathrm{PS}-\mathrm{PB}^{\mathrm{d}}$ component ( $\mathrm{PB}^{\mathrm{d}}$ is deuterated polybutadiene) in the diblock copolymer superlattice depending on the number of neighbourting $\mathrm{PB}$ chatng having the low molecular mags $\left(\mathrm{M}_{\mathrm{p}}=38 \cdot 10^{3}\right)$. With 
this end in view, the block copolymers 1 and 2 were mixed in the ratios 2:1 and 5:1 by the number of chains. Pllms were obtained by casting from toluene solutions on lapsan sublayer. The dry f1lms w1th the thickness about $0.7 \mathrm{~mm}$ were cut in the stripes of $2 \mathrm{~mm}$ width and $60 \mathrm{~mm}$ length. These stripes have been packed as a pile of $2 \times 5 \times 60 \mathrm{~mm}^{3}$. It was experimentally determined that BO $1,2,3$ and their mixtures formed common lamellar structures with lamellae oriented parallel to the f1lm surface [3].

Small-angle neutron scattering experiments have been performed on the "Membrana-2" instrument [4]. The wavelength of the incident neutron bean is $\bar{\lambda}=2.3 \mathrm{~A}$, the halfwidth of the spectrum is $\Delta \lambda / \bar{\lambda}=0.10$.

The perfod of lamellar superatructure D was measured for all samples orlented parallel to the beam. To determine $\mathrm{R}_{\mathrm{gx}}$ projection of PB chain we ortented f1lms perpendicular to the beam (T-orientation). In this case we measured the scattering curves from the protonated sample (background) and from the sample containing $3 \%$ of deuterated PB chains (block copolymer 3), then the difference in the scattering curve has been obtained by subtracting these two signals.

3.Results and discussion.

The scattering intensity for deuterated PB chains was expressed In the Guinier law Porm:

$$
I(Q)=\mathrm{I}(0) \cdot \exp \left(-Q^{2} \mathrm{R}_{\mathrm{gx}}{ }^{2}\right)
$$

where $R_{g x}$ is the radius of gyration of the chain along $x$-direction, $Q=4 \pi \operatorname{in} \theta / \lambda$, and $2 \theta$ is the scattering angle.

The data obtatned are given in Table 2. The calculated value of the unperturbed $\mathrm{R}_{\mathrm{gx}}$ for the $\mathrm{PB}^{\mathrm{d}}$ block is $76 \frac{\mathrm{A}}{2}$. The $\mathrm{R}_{\mathrm{gx}}$ of the long chain can be expressed in the form $R_{g x, 1}^{2}=u_{g x, 1} R^{2}{ }^{2} R_{g x, 1}^{2}$, where $u^{R} R_{g x, 1}$ and ${ }_{1} R_{g x, 1}$ are the radil of gyration of the parts of the chain in the upper and lower sublayers, correspondingly, of the 1-th mixture (see Tabl.2). The value ${ }_{1} R_{\mathrm{gx}, 1}=23$ \& was calculated on the basis of 
Table 2

The period of lamellar structure $D$ and $R_{g x}$-projections of radii of gyration of $P^{d}$-chain for block copolymer mixtures of different composition.

\begin{tabular}{lclcl}
\hline Polymer & BC1 & BC2 & $\begin{array}{c}\text { BC1:BC2 } \\
(2: 1)\end{array}$ & $\begin{array}{c}\mathrm{BC1}: \mathrm{BC2} \\
(5: 1)\end{array}$ \\
\hline$\overline{\mathrm{D}}, \AA$ & $465 \pm 15$ & $905 \pm 20$ & $775 \pm 15$ & $695 \pm 15$ \\
\hline $\mathrm{R}_{\mathrm{g} x, 1, \mathrm{~A}}$ & - & $45.1 \pm 1.9$ & $54.9 \pm 2.8$ & $61.9 \pm 3.1$ \\
\hline
\end{tabular}

the theoretical model assuning Gaussian conformation for chaing $[3,5]$. These values are the same for all mixtures studied. Consequently one can obtain: $u^{R} g x, 1=39 \AA, u^{R} g x, 2=50 \AA$ and $\mathrm{u}_{\mathrm{gx}, 3}=57 \&$. The calculated value of the unperturbed upper part of the chain is $\mathrm{u}_{\mathrm{gx}}^{\mathrm{R}}=69$ \&. Thus the effect of lateral contraction of the chain in the domain structure is rather strong [5].

Now let us consider the variation of the period of the lamellar structure. As developed in the theory [2] the variation of D depending on the layer composition can be written as follows:

$$
\mathrm{D}=\mathrm{D}_{\mathrm{O}}+2 \mathrm{q}_{2}\left(\mathrm{H}_{0}^{\mathrm{PS}} \mathrm{a}_{\mathrm{PS}}+\mathrm{H}_{0}^{\mathrm{PB}} a_{\mathrm{PB}}\right) \text {, }
$$

where $\mathrm{D}_{\mathrm{O}}$ is the period of initial monodispersed structure, $\mathrm{H}_{0}^{\mathrm{PS}}$. $\mathrm{H}_{0}^{\mathrm{PB}}$ are the heights of Initial monodispersed layerg of PS and PB, $a_{\mathrm{PS}}$ and ${ }^{a_{\mathrm{PB}}}$ are the relative differences in chain lengths for PS and $\mathrm{PB}, a=\left(\mathrm{N}_{2}-\mathrm{N}_{1}\right) / \mathrm{N}_{1} \quad\left(\mathrm{~N}_{2}\right.$ and $\mathrm{N}_{1}$ are the polymerization degrees of short and long chains) and $q_{2}$ is the fraction of long chains in the layer. At the same time for homodispersed diblock copolywers [6]:

$$
\mathrm{D}=\mathrm{km}_{\mathrm{n}}^{0.64} \text {. }
$$

Here $y_{n}$ is the number-average molecular weight of the BC. If the the bldispersed layer is consldered as a layer of chains with the same molecular welght $u_{\text {eff }}$, we would calculate $D$ using relation (3). In F18.2 these dependences are given along with the exper1- 
mental one.

It is obvious that the changes in the real superlattices formed

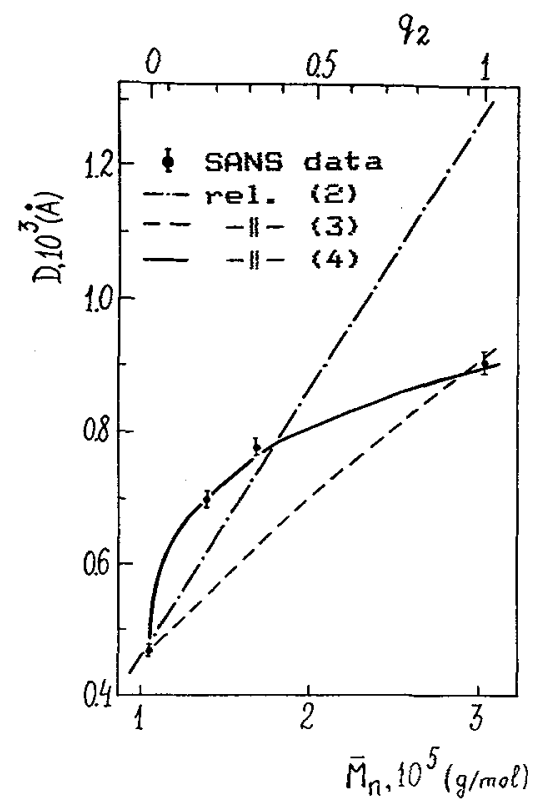

P1g.2. The dependence of the supergtructure period $D$ on the composition of block copolymers.

by bldispersed mixtures are not well described efther by the theorleg developed for homodispersed chains or by those developed for bidispersed systems when the layer is separated in two independent sublayers. Te suggest an empirical relation of $D$ on the composition of bidispersed layers which describes adequately the dependence obtalned:

$$
\mathrm{D}=\mathrm{D}_{0}+\mathbf{x} \mathbf{m}_{\mathrm{n}}^{1 / 3},
$$

here $M_{n}$ is an effectfve molecular weight of the upper part of the laver. The dependence $\mathrm{D}\left(q_{2}\right)$ calculated using (4) is given in PIg.2. Th1s dependence corresponds to free (ungrafted) monodispersed chains in the clrcumstances where their density is constant. 
Thus, we can formulate the following conclusions for real block copolymers on the basis of the data obtained. It 1s-observed that the conformation of lower parts of the chatns (gee F1g-1) depends on ne1ther the length nor the concentration of long chains. However, in the upper sublayer the conformation of those parts of long chains which occupy this sublayer is not consistent with theoretical predictions developed both for homo- and bidispersed chains. We conclude that intermolecular interactions between chains affect their conformation and these effects should be taken into account. We thank Dr. Vinogradova I. of Institute of kacromolecular Compounds for the synthesis of samples.

\section{RERFERKNCES}

[1] Hadz1loannou G., Skoulios A. Macromolecules, 1982, 15, 267.

[2] Birghtein T.M., Liatgkaya Yu.V., Zhulina B.B. Polymer, 31 (1990), 2185.

[3] G.A.Evmenenko, V.I.Alexeev, A.D.Vilesov. Preprint PNPI (1992), 1806.

[4] Agamalyan M.M., Drabkin G.M., Svergun D.I., Peigin L.A. Preprint INPI (1990), 1599.

[5] V1lesov A.D., Evmenenko G.A., Zachmann H.G. In: Trends in non-crystalline solids, Ed. A.Conde, G.F.Conde, M.M1llan, World Scientific, Iondon (1992), 89.

[6] Helfand E., Wassermann Z.R. In: Developments in block copolymers-1; Bd. Goodman I., Applled Sc1ence Publishers: N.Y. (1985), chapter 4. 